programmes with limited placement, men are often favoured over women. Being a female head of household allowed her to receive these services without "bucking the system" before she knew how "the system" operated.

Finally, the fact that she was surrounded by a network of supportive female kin enabled her to reassert control over the reunited family. As her English skills increased, she and her mother became key figures in family decision- making. Her mother retains her position as head of the family, even though she speaks virtually no English and has no intention of learning any.

The personal characteristics that contributed to her successful adjustment include her absolute realism; her capacity to live in the present and retain a sense of humour and serenity throughout; her ability to accept the loss of her children and her wealth; her persistence in attempts to obtain all possible rights and opportunities available to her as a refugee. During the most difficult months after resettlement, she was saved from the depths of depression facing many of her family members by her optimism and practicality (her pride did not stop her from accepting used clothes, unlike some of her relatives). She refused to acknowledge her marginal position in society and lack of opportunities, attributing her problems to her lack of sufficient English skills and the economy. As a result of this attitude, she continued to seek out business opportunities, confident of her abilities and business potential.

Her entrepreneurial excitement should not be stilled: perhaps it will even be contagious, infecting her refugee sisters with a renewed vision of women's potential and new strategies for changing existing conditions. Judging from one woman's struggle, the women of Southeast Asia who come as refugees will enrich our lives and contribute a sense of detached, composed strength which cannot be compromised. For they know their worth.

Penny Van Esterik is Associate Professor of Anthropology at York University specializing in Southeast Asia.

\title{
Refugee Women in Canada: The Lingering Effects of Persecution, War and Torture
}

\author{
by Mary Carmen Romero-Cachinero
}

Since the Second World War, it is estimated that about half a million refugees have settled in Canada, about half of whom were women. Despite the great differences in their social, economic and cultural backgrounds, these women share a common experience of escaping from lifethreatening circumstances. They also share the experience of being forced to abandon their homes and native lands, with all the trauma that entails. Finally, most refugee women share the status of "sponsored relatives" upon arrival in Canada, a category which generally denies their tnue plight.

What effect does this traumatic background have on their adjustment to life in Canada? Let us look briefly at three individual cases. The names of the three people have been changed to maintain confidentiality.

Case 1: Maria is twenty-three years old. She came from South America. Her father was tortured to death and her only brother managed to flee the country after having been detained and tortured himself. Though very young, Maria was forced to leave school and earn her living as a sales clerk. She became an active member of a local union, and as such was subject to harassment by the police. She received threatening phone calls, her family's home was regularly searched, and her mother beaten. She was detained for five days in solitary confinement and interrogated, beaten, and raped. She was also threatened with being made to "disappear" (as her father did) if she did not become a police informer. Upon her release, María fled to Canada. She had to undergo a process of one and a half years to have her claim as a sponsored refugee accepted.

Maria has found her adjustment to Canada very difficult. She is subject to periodic bouts of severe depression, anxiety and intense rage against the authorities of her country of origin.
Case 2: Lillian is in her early thirties and comes from a country in Eastem Africa. During a political upheaval in her native land, her fiancé, along with many others, was detained by the authorities, and never heard from again. She was later detained at work and accused of being disloyal to the new military regime. Lillian spent over five months in prison, without charges being laid against her. She was deprived of adequate food, water, clothes, medical care, and forced to live in an overcrowded and dirty cell. Eventually, her fiance's family was able to provide sufficient money to gain her release and she escaped to a nearby country without contacting her family. After two years she was sponsored by a Canadian church group to immigrate to Canada as a refugee.

Even though she could speak English, her professional qualifications (hotel management) have never been accepted, and she has been forced to support herself doing cleaning. Alone in Canada, she has experienced great loneliness and lack of support, which she has tried to overcome by becoming actively involved in church activities.

For years, she has retained the belief that her fiancé is still alive, a situation which has inhibited the development of new relationships with men. She lives in constant anxiety about the safety of her family in her country of origin.

Her brother-in-law disappeared leaving her sister with three young children to support. The worst blow of all was when she received the news that her fifteen-year old sister had been raped, murdered an, decapitated. Lillian herself, in addition her psychological trauma, still suffers $t^{\text {. }}$. physical effects of her ordeal. She 6 permanent kidney damage and numers. scars all over her body from the beatif: that she received while in detention.

6 
Case 3: Rosa is a twenty-four year-old Central American with three children. Shortly after the birth of her third child, Rosa went to live with her parents in order to escape the violent and abusive behaviour of her husband. Her husband was accepted into Canada as a Convention refugee and he arranged to sponsor Rosa and her children to come to Canada. Rosa agreed, because of her constant fear of violent death and torture in her homeland.

As Convention refugees in Canada, they received the basic assistance offered by the Federal Department of Employment and Immigration. Although Rosa is now free from the political violence of her homeland, she is once again in a situation of violence. She and her children are regularly subjected to abuse from her husband. He sometimes takes the government support allowance for himself; when that happens, Rosa is forced to rely on charities. Rosa would like a divorce, but has decided to put up with the present situation because she is afraid of being deported (as she is a sponsored relative, she is thus dependent on her husband), losing custody of her children and not having any support from her husband. Not knowing English, her only friends are other Spanish-speaking refugees. She would like to finish her high school education, learn English and take some kind of vocational education, but finds this impossible in her present situation. Finally, Rosa, like the others, experiences much anxiety about the safety of her family in Central America, and feels guilt because of her inability to send them any help.

Refugee women face the same obstacles as other immigrant women: language barriers, cultural differences and culture shock, economic constraints and racial discrimination. As is clear from the cases outlined above (which are similar to thousands of others), refugee women need to overcome the psychological scars left by traumatic and violent experiences. Nevertheless, whether they arrive as refugee claimants (Maria), privately sponsored refugees (Lillian), or as sponsored relatives (Rosa), they have little chance of getting either initial or ongoing assistance in their struggle to overcome their psychological problems. Because of this lack of support and counselling, their problems often persist indefinitely.

Even though every case is unique, there are some psychological effects which have a higher incidence among refugee women than among other immigrant women.1 Some of these symptoms include: general anxiety and depression, guilt (about inability to assist families left behind), fearfulness, paranoia, insomnia, psychosomatic illness, and menstrual irregularities.2

Some of these symptoms may not appear immediately on arrival in Canada. ${ }^{3}$ Commonly, during the first few months (sometimes years) in their new country, refugees experience the so-called "honeymoon effect". This period of euphoria eventually turns into a period of realism about the difficulties of adjustment in the new land. It is during this somber period that the ghosts of their past experience emerge. Very often they are reluctant to talk about their psychological problems to their new acquaintances, people who can hardly imagine the circumstances that gave rise to these problems. These people very rarely search for help outside of their immediate circle, primarily because there is an almost

1 G. Cowgill and G. Doupé, "Recognizing and Helping Victims of Torture", The Canadian Nurse (December 1985), pp. 18-22.

2 E. Domovitch, P. Berger et al, "Human Torture: Description Sequilae of 104 Cases", in Canadian Family Physician, 30 (April 1984), 827-83.

3 C.J. Frederick, "Violence and Disaster: Immediate and Long Term Consequences", in Helping Victims of Violence (The Hague: Ministry of Welfare, Health and Cultural Affairs, Government Publishing Office, 1983), pp. 32-46. complete lack of services directed to the support and guidance of refugee women.4

In 1986, the Secretary of State and the Department of Health and Welfare organized a task force to prepare an indepth study of the special mental health needs of immigrants and refugees in Canada. The twelve-member task force is exploring the circumstances contributing to stress among the newcomers. During its two-year mandate, the task force will summarize existing research and will call for briefs from concerned organizations and individuals across the country. Fortunately, refugee women will be addressed as a target group. We can expect that the report will pinpoint the severe lack of culturally and linguistically sensitive services for refugee women (English as a Second Language (ESL) classes, vocational counselling, psychological counselling, etc.). It is hoped, therefore, that the final report will makc governments and health service agencies sensitive to the needs of refugee women and will lead to the establishment of appropriate mental health and orientation services. In the meantime, ethno-cultural communities should become activcly involved in lobbying for these programmes. Ultimately, it is within the boundaries of their neighbourhoods and communities that refugee women can either be helped or continue to be neglected.

4 I. Kaprielian, "Creating and Sustaining an Ethnocultural Heritage in Ontario: The Case of Armenian Women Refugees", in Looking into My Sister's Eyes: An Exploration in Women's History, edited by Jean Bumet (Toronto Multicultural History Society of Ontario 1986), pp. 139-153.

Mary Carmen Romero-Cachinero is a PhD candidate at OISE and has worked as a refugee counsellor. Currently she is co-ordinating ESL programmes for Spanish-speaking refugees. 